\title{
Language students learning to manage complex pedagogic situations in a technology-rich environment
}

\author{
Riikka Tumelius ${ }^{1}$ and Leena Kuure ${ }^{2}$
}

\begin{abstract}
Being a language teacher in the modern world requires sensitivity to complexity, which may pose challenges for student teachers and teachers in the field accustomed to classroom-based learning and teaching. This study examines how language students are managing complex pedagogic situations in a technologyrich environment while exploring new ways of being language teachers. The case context of the study is a university course, which entailed the students designing and carrying out an online English language project for fifth-graders in two Finnish schools. The project activities included online chat sessions, which the students and the course teacher administered from the teacher's office at the university. The office was an important site for the participants to negotiate and process pedagogic issues and practical matters that arose in the course of the work. The research approach draws on nexus analysis (Scollon \& Scollon, 2004) and multimodal (inter)action analysis (Norris, 2004). Video recordings from the office as well as the researchers' participatory observations are the primary materials for the analysis. The study provides implications for developing language teacher education.
\end{abstract}

Keywords: language teacher education, sensemaking, complexity, nexus analysis.

\section{Introduction}

Despite the arrival of new technologies for the service of education, people still typically see language learning situated in the classroom. Language teachers have been guides for learners to proceed through activities arising from the thematic content of the textbook (Taalas, Kauppinen, Tarnanen, \& Pöyhönen, 2008). Teaching practice as part of pedagogic studies has also largely concentrated on preparing students to handle classroom situations. However, educational authorities and

1. University of Oulu, Oulu, Finland; riikka.tumelius@oulu.fi

2. University of Oulu, Oulu, Finland; leena.kuure@oulu.fi

How to cite this article: Tumelius, R., \& Kuure, L. (2017). Language students learning to manage complex pedagogic situations in a technology-rich environment. In K. Borthwick, L. Bradley \& S. Thouësny (Eds), CALL in a climate of change: adapting to turbulent global conditions - short papers from EUROCALL 2017 (pp. 312-316). Research-publishing.net. https://doi.org/10.14705/rpnet.2017.eurocall2017.732 
strategic bodies have voiced the need to broaden the perspective from classrooms to learning in daily life. The sites for language learning are diverse, distributed across informal and formal settings in hybrid configurations (see Ryberg, Davidsen, \& Hodgson, 2016). Language learning emerges from meaningful activities and social interaction where language intertwines with a range of other multimodal resources (Kramsch \& Whiteside, 2008; Norris, 2004; van Lier, 2004).

In situations where people need to manage multiple, overlapping tasks, the coordination of the activities proceeds through distributing attention and engaging in sensemaking in different ways due to emerging needs (see Jones, 2005; Norris, 2004; Pirini, 2014). Team members monitor surreptitiously the situation and the behaviour of each other, which helps them in upholding a fluent workflow while information is communicated and diverse tasks and activities coordinated (Heath \& Luff, 1992). The modal density of actions fluctuates from moment to moment the focus of attention moving between foreground, mid-ground, and background (Norris, 2004).

We will examine how language students appropriated new approaches to being teachers during a university course where the students designed and carried out an online learning project for young Finnish learners of English. The analysis focuses on the activities during tutoring sessions in the course teacher's office, and is conducted on video recordings with the support of other materials gathered throughout the project. Special attention is paid to how different issues and problems related to pedagogic issues, collaboration, and technology are negotiated and resolved by the participants and how this will reflect on the students' evolving identities as language teachers of the future. The research approach draws on nexus analysis (Scollon \& Scollon, 2004) and multimodal (inter)action analysis (Norris, 2004). Research in the field is only emerging. The results have relevance for reconsidering the professional profiles, identities, and skills of language teachers in the changing field of language education.

\section{Research materials and methodology}

During the course (13 weeks), 15 language students created a four-week learning project for two schools (25 fifth-graders, 11-12 years of age). Project design advanced through face-to-face and online teamwork. During the school project, weekly synchronous chat sessions were organised with the pupils during their English lessons. To administer online chat, the students worked together with the course teacher in her office. Sometimes, an additional tutor from a distance location 
participated in the activities. During the sessions, the team practiced managing complex pedagogic situations, but also engaged in sensemaking about various aspects of learning and teaching together with the course teacher.

As for the affordances of technology in the sessions, one desktop and two laptop computers with webcams were available for the participants. The primary route for the pupils to enter the learning project environment was the workspace created on a virtual learning environment platform. Depending on the activities, the pupils used the materials and discussion lists there or used a link to proceed to another environment, such as the chat built within a desktop meeting system. The course teacher and the schoolteachers were using an instant messaging tool and mobile phones for exchanging information and negotiating about practical matters during the chat session. Two video cameras were used for recording the sessions.

The analysis started with the researchers viewing the materials and discussing their interpretations with respect to the aspects of social action according to nexus analysis (Scollon \& Scollon, 2004, pp. 13-14), i.e. interaction order (relationships between participants), historical body (personal habits and experiences), and discourses in place (situationally foregrounded, relevant discourses). This supported reflection on the historical perspectives, e.g. what was being treated as belonging to the past, present or future. In viewing the video material, the focus was directed to what was being done, what were the discourses circulating in situ, and what kinds of multimodal means were used as resources in collaboration, problem solving, and sensemaking (Norris, 2004).

\section{Findings}

Figure 1 provides a synthesis of an online tutoring session in the teacher's office as a site of engagement (Jones, 2005). As the participants immersed themselves in managing a new pedagogic setting, diverse discourses were circulating in the situation, echoing accustomed practices and generating new ones.

The students and the teacher in the office were engaged in varied activities, e.g. distributing tasks and responsibilities as well as contemplating on course design. An intensive phase requiring various means for communication took place at the beginning of the chat session when the teacher was in contact with the schoolteachers (via mobile phone and messenger) and the tutoring students were engaged in a chat with the pupils through the video conferencing system. During work, topics related to pedagogic aspects either closely related to the work 
at hand or more general in nature emerged. In the discussion, the participants were reflecting on their experiences, exploring their relationship to being language teachers. Sometimes, the course teacher took more the role of an instructor, and sometimes she just participated in the joint activities as another team member. They all kept thinking aloud, wondering and solving issues together in a laid-back manner. The students were offering their views in the negotiation work and they assumed agency in the situation. Considering the traditional roles of learners and teachers, this setting provided new experiences for the participants.

Figure 1. Intersecting discourses during an online tutoring session

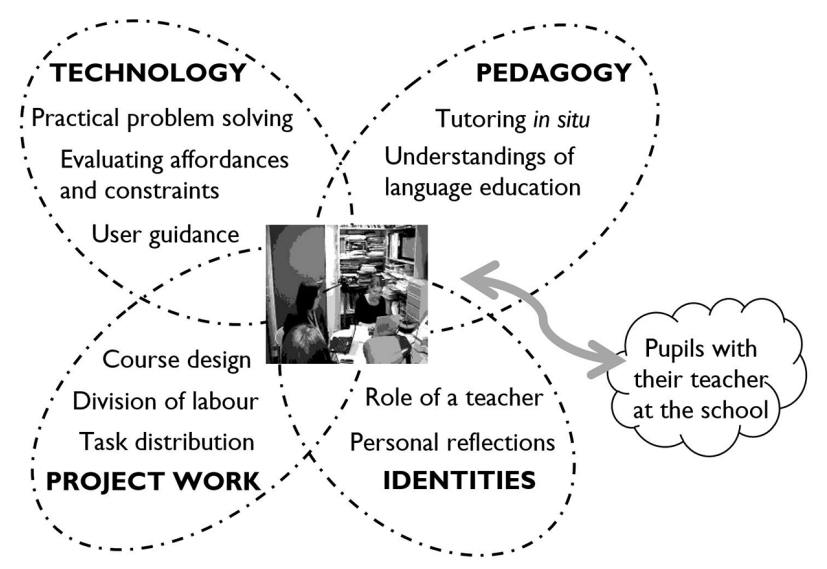

\section{Conclusion}

The analysis focused on what was going on when language students were designing and carrying out a learning project for schoolchildren. Special attention was given to managing complex pedagogic situations in a technology-rich environment. The historical bodies of the participants were being transformed in terms of language education as the participants were working in new roles, gaining new experiences and engaging in sensemaking about practical solutions and broader pedagogic issues to do with language learning. Such experiences involved novel configurations of interaction order as the students and the course teacher were collaboratively solving problems as equal members of the team while simultaneously connected with participants at a distance. The language teacher's work involved technologymediated multitasking and continuously negotiating solutions related to the ongoing learning project. The video data from the office showed the students 
appropriating new practices as language teachers without any great difficulty. The discourses emerging during work also indicated that assuming new identities is a slow process. Nevertheless, the students gained valuable hands-on experience of technologically mediated language teaching, which helps them in constructing their vision of future working life.

\section{Acknowledgements}

We would like to thank the participating schools and the language students designing and implementing the school project for active participation in collaboration.

\section{References}

Heath, C., \& Luff, P. (1992). Collaboration and control: crisis management and multimedia technology in London underground line control rooms. Journal of Computer Supported Cooperative Work, 1(1), 24-48. https://doi.org/10.1007/BF00752451

Jones, R. H. (2005). Sites of engagement as sites of attention: time, space and culture in electronic discourse. In S. Norris \& R. Jones (Eds), Discourse in action: introducing mediated discourse analysis (pp. 144-154). Routledge.

Kramsch, C., \& Whiteside, A. (2008). Language ecology in multilingual settings: towards a theory of symbolic competence. Applied Linguistics, 29(4), 645-671. https://doi.org/10.1093/ applin/amn022

Norris, S. (2004). Analyzing multimodal interaction. A methodological framework. Routledge.

Pirini, J. (2014). Producing shared attention/awareness in high school tutoring. Multimodal Communication, 3(2), 163-179.

Ryberg, T., Davidsen, J., \& Hodgson, V. (2016). Problem and project based learning in hybrid spaces: nomads and artisans. In S. Cranmer, N. Bonderup Dohn, M. de Laat, T. Ryberg, \& J.-A. Sime (Eds), Proceedings of the 10th International Conference on Networked Learning 2016 (pp. 200-209). Lancaster University.

Scollon, R., \& Scollon, S. W. (2004). Nexus analysis: discourse and the emerging internet. Routledge.

Taalas, P., Kauppinen, M., Tarnanen, M., \& Pöyhönen, S. (2008). Media landscapes in school and in free time - two parallel realities? Digital Kompetanse - Nordic Journal of Digital Literacy, 3(4), 240-256.

Van Lier, L. (2004). The ecology and semiotics of language learning: a sociocultural perspective. Kluwer Academic. https://doi.org/10.1007/1-4020-7912-5 


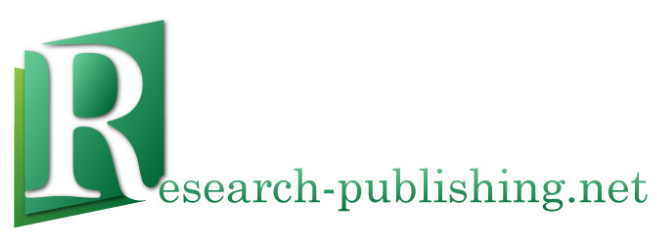

Published by Research-publishing.net, not-for-profit association Contact: info@research-publishing.net

(C) 2017 by Editors (collective work)

(C) 2017 by Authors (individual work)

CALL in a climate of change: adapting to turbulent global conditions - short papers from EUROCALL 2017 Edited by Kate Borthwick, Linda Bradley, and Sylvie Thouësny

Rights: This volume is published under the Attribution-NonCommercial-NoDerivatives International (CC BY-NC-ND) licence; individual articles may have a different licence. Under the CC BY-NC-ND licence, the volume is freely available online (https://doi.org/10.14705/rpnet.2017.eurocall2017.9782490057047) for anybody to read, download, copy, and redistribute provided that the author(s), editorial team, and publisher are properly cited. Commercial use and derivative works are, however, not permitted.

Disclaimer: Research-publishing.net does not take any responsibility for the content of the pages written by the authors of this book. The authors have recognised that the work described was not published before, or that it was not under consideration for publication elsewhere. While the information in this book are believed to be true and accurate on the date of its going to press, neither the editorial team, nor the publisher can accept any legal responsibility for any errors or omissions that may be made. The publisher makes no warranty, expressed or implied, with respect to the material contained herein. While Research-publishing.net is committed to publishing works of integrity, the words are the authors' alone.

Trademark notice: product or corporate names may be trademarks or registered trademarks, and are used only for identification and explanation without intent to infringe.

Copyrighted material: every effort has been made by the editorial team to trace copyright holders and to obtain their permission for the use of copyrighted material in this book. In the event of errors or omissions, please notify the publisher of any corrections that will need to be incorporated in future editions of this book.

Typeset by Research-publishing.net

Cover design based on (C) Josef Brett's, Multimedia Developer, Digital Learning, http://www.eurocall2017.uk/, reproduced with kind permissions from the copyright holder.

Cover layout by (C) Raphaël Savina (raphael@savina.net)

Photo "frog” on cover by (C) Raphaël Savina (raphael@savina.net)

Fonts used are licensed under a SIL Open Font License

ISBN13: 978-2-490057-04-7 (Ebook, PDF, colour)

ISBN13: 978-2-490057-05-4 (Ebook, EPUB, colour)

ISBN13: 978-2-490057-03-0 (Paperback - Print on demand, black and white)

Print on demand technology is a high-quality, innovative and ecological printing method; with which the book is never 'out of stock' or 'out of print'.

British Library Cataloguing-in-Publication Data.

A cataloguing record for this book is available from the British Library.

Legal deposit: Bibliothèque Nationale de France - Dépôt légal: décembre 2017. 